\title{
The Effect of Biology Learning Using Concept Attainment Model and Discovery Learning on the Problem Solving Ability
}

\author{
$1^{\text {st }}$ Yuliati \\ Master Program of Science Education, \\ Sebelas Maret University \\ Surakarta, Indonesia \\ yuliayuli586@gmail.com
}

\author{
$2^{\text {nd }}$ Maridi \\ Faculty of Teacher Training and \\ Education \\ Sebelas Maret University) \\ Surakarta, Indonesia \\ maridi@staff.uns.ac.id
}

\author{
$3^{\text {rd }}$ Mohammad Masykuri \\ Faculty of Teacher Training and \\ Education \\ Sebelas Maret University) \\ Surakarta, Indonesia \\ masykuri@fkip.uns.ac.id
}

\begin{abstract}
This paper presents a new approach to determine the difference in problem-solving abilities between students treated with a concept attainment model and those treated with discovery learning model. This study was experimental research. The population of the study was 12th graders of Science in the 1st Public Senior High School of Karas (Indonesian: SMA Negeri 1 or SMAN 1 Karas), Magetan Regency, in academic year 2016/2017. The sample was taken using cluster random sampling technique, consisting of two classes: class XII Science 4 as the first experimental class using concept attainment model and class XII Science 3 as the second experimental class using discovery learning model. The technique of collecting data used an independent sample T-test technique for problem-solving test results. The data analysis was carried out using the mean difference test of two unpaired samples. The results showed that there was a difference between students' learning outcomes between students treated with a concept attainment model and those treated with discovery learning model. The students who were taught using the concept attainment model was higher than they who were taught using a discovery learning model.
\end{abstract}

Keywords - concept attainment model, discovery learning, problem-solving ability

\section{INTRODUCTION}

One of the National Standards of Education, which is the process standard, states that learning processes at educational unit level are organized interactively, inspiringly, and joyfully to challenge and motivate the students in participating in class actively, and to provide space for initiative, creativity, and independence according to students' talent, interest, and physical and psychological developments [1]. In Biology learning, the students in SMAN 1 Karas, Magetan Regency study concepts, and principles only by reciting. So many concepts and principles in science to studied leads to the student's boredom in learning science. Learning model and methods used in SMAN 1 Karas in the learning process has not varied yet. Lecturing method is used very dominantly by teachers in the learning process. One of biology learning materials is evolution. Evolution material presents information about events in the past widely, in which one concept is interrelated to another [2]. This characteristic of material makes the students find difficulties in organizing concepts, clarifying each concept and combining one concept and another. The delivery of lecturing material cannot overcome the students' difficulties in organizing and clarifying the concept so that the learning model is needed which can help the students master the concept of science concept.

Kumar \& Mathur [3] stated that various teaching approaches have evolved to design instruction, but the most appropriate teaching approach/model with good, effective, efficient and exciting impacts can only be answered through research using the learning model to find out its effect on the students. Kumar \& Mathur research used the concept attainment model to teach specific concepts by comparing and differentiating examples containing concepts and those not containing concepts. The concept attainment model builds on the study of students' thinking conducted by Bruner, Goodnow, and Austin in 1967. This attainment concept model learning is relatively closely related to the inductive learning model. Concept attainment and inductive learning models are designed to analyze, develop, and teach concepts and to help students learn concepts more effectively [4].

Concept attainment model can help students elaborate concepts using thinking process analysis so that students are able to discover and achieve their concepts to strengthen knowledge in long-term. In this learning, the students are involved in various levels of participation in learning that can present organized information from a broad topic to right topic of the inductive process [5]. Mayer [6] described the concept attainment model as a way of providing inductive learning to help students develop critical thinking skills and get a better understanding. This learning model, according to Mayer, makes the students think more independently, apply their knowledge, and develop inductive thinking skills to be prepared better for the future life. Students learn better when using analogies and real examples in Biology learning.

Bhargava [7] in his study stated that the group of students with concept attainment model learning has achieved significantly better than the one with the conventional model (control group) does. This model was conducted initially by Fraizer [8] the concept attainment model, objectives, 
teachers' duty/task, and students in this model application, from pre-school to high school, as well as the effectiveness of this model in various learning; secondly, Sreelekha and Nayar [9] comparing the achievement levels of traditional methods and concept attainment models in relation to knowledge, understanding and objective application. The main finding is that concept attainment model is effective in improving the overall level of concept achievement in Chemistry subjects; thirdly, Shamnad [10] conveyed that concept attainment model is more effective than control method in the IX class. Kalani [11] found that the achievement of students taught with concept attainment model is better than those taught with control method. Ostad and Soleymanpou [12] reported that teaching with concept attainment model and concept mastery affects the students' academic achievement and cognitive ability. Studies conducted on the concept of model attainment illustrate that students learn better when taught using this model.

Considering the description above and as the solution to overcome the students' difficulties all at once, a study on Biology learning model is conducted by applying learning model that can present information that has been organized from broad topic to understandable one, the concept attainment achievement. Finding out the extent to which this model use has been successful, discovery learning model is used as a comparator. The learning using discovery learning model is also a student-centered learning model. Discovery is a method which offers the learners an opportunity of discovering scientific facts, concepts, and principles for themselves. Thus, the learners get an opportunity of discovering and learning science from their participation. [13].

A recent review of the literature found that students were taught with concept attainment model have better outcome in their knowledge, understanding, classification, the way of thinking and way of accepting the concept. This model enables the students to be more sophisticated in conceptualization, inductive reasoning, dominance and knowledge of vision, perspective, tolerance to ambiguity and sensitivity to logical reasoning in communication. Concerning problem-solving abilities, students taught with concept attainment model will have a high problem-solving ability. The problem-solving process involves problem identification, using knowledge to create new concepts about the problem, and using effective strategies to solve the problem. Skills required in problem-solving include ideal solution, creativity, flexibility, and reorganization. All these components are needed in decision making every day. Jules also explained that the problem-solving process requires a significant amount of information and the reduced ability to process a significant amount of information to make the right decision can lead to problem-solving error [14].

Sternberg [15] suggested that problem-solving ability is accomplished in the following steps: 1) identifying problem; 2) defining problem; 3) constructing strategy for problemsolving; 4) organizing information about the problem; 5) monitoring the problem solving; 6) evaluating the problemsolving. This study used the problem-solving instrument developed by Paidi [16] consisting of 5 indicators: 1) define the problem; 2) identify the problem; 3) formulate alternative solutions; 4) determine the best solution; 5) problem-solving ability.

Considering the reasons explained above, the author wants to find out whether there is a difference of problem-solving ability or not between the $12^{\text {th }}$ graders Science taught with concept attainment model and those taught with discovery learning in Evolution material in SMAN 1 Karas in academic year 2016/2017.

\section{METHODS}

The research was taken place in SMAN 1 Karas Magetan district, Kendal Highway, Temenggungan Village, Karas District, Magetan Regency, East Java, in the second semester of the academic year of 2016/2017. The study proceeded from preparing the proposal by reporting the study, from the end of the $1^{\text {st }}$ semester of October 2016 through July 2017. This study was quantitative descriptive research with an experimental method. The research design used in this study was Post-test Only with Nonequivalent Groups in which the author treats one group as an experimental group and then another as a control group. Next, the post-test was conducted in both groups. Both class groups in the study were used to find out the effect of the independent variable on the dependent variable. The first experimental class was treated with the concept attainment model and the second one with discovery learning model, and the posttest was given to the two groups. The data collected was then processed and analyzed to find out whether there is a difference of problemsolving ability between the $12^{\text {th }}$ Science graders of SMAN 1 Karas Magetan Regency using concept attainment model and those using discovery learning model. The population of research was the $12^{\text {th }}$ Science graders of SMA Negeri 1 Karas, Magetan Regency, in academic year 2016/2017 consisting of five classes. The sample was taken using cluster random sampling technique, consisting of two classes receiving different treatments. The $12^{\text {th }}$ Science 4 grade as the first experimental class used the concept attainment model and the $12^{\text {th }}$ Science 3 as the second experimental class used discovery learning model.

Techniques of collecting data used this research were (1) documentation technique, constituting the score of four typical majoring subjects of the even semester of $11^{\text {th }}$ grade as the basis of class establishment, so the $12^{\text {th }}$ grader has been homogenous as the population; (2) data collection instruments in the form of problem solving test. The experts performed the validity test on syllabus and learning implementation plan instruments (e.g., lecturers and education practitioners) before they were used. The problemsolving test was not validated because it has been developed previously and proved for its validity. The statistical test used on the difference was independent sample T-test that has undertaken a prerequisite test previously, including normality and homogeneity tests. The data normality test was carried out using Kolmogorov-Smirnov analysis. The criterion of testing criteria was that if sig obtained $>\alpha$, the data would generally be distributed at the significance level of $5 \%$. Homogeneity test was carried out using the Levene test. When significance or probability value $>0.05$, the data is 
considered as homogeneous. The test was conducted using SPSS 18.

\section{RESULT AND DISCUSSION}

\section{A. Result}

The learning was conducted in four meetings. It was then continued with the $5^{\text {th }}$ meeting, the problem-solving ability test. The score result of problem-solving ability post-test for each of the indicators can be seen in the table below.

TABLE I. OBTAINING THE SCORE IN EACH INDICATOR

\begin{tabular}{clcc}
\hline No & Indicators & $\begin{array}{c}\text { Experiment } \\
1(\mathrm{CAM})\end{array}$ & $\begin{array}{c}\text { Experiment } \\
\text { (DL) }\end{array}$ \\
\hline 1 & Defining Problems & 62 & 60 \\
\hline 2 & Identifying the problem & 42 & 41 \\
\hline 3 & Formulating alternative solutions & 39 & 37 \\
\hline 4 & Determining the best solution & 40 & 37 \\
\hline 5 & Problem-solving abilities & 41 & 40 \\
\hline
\end{tabular}

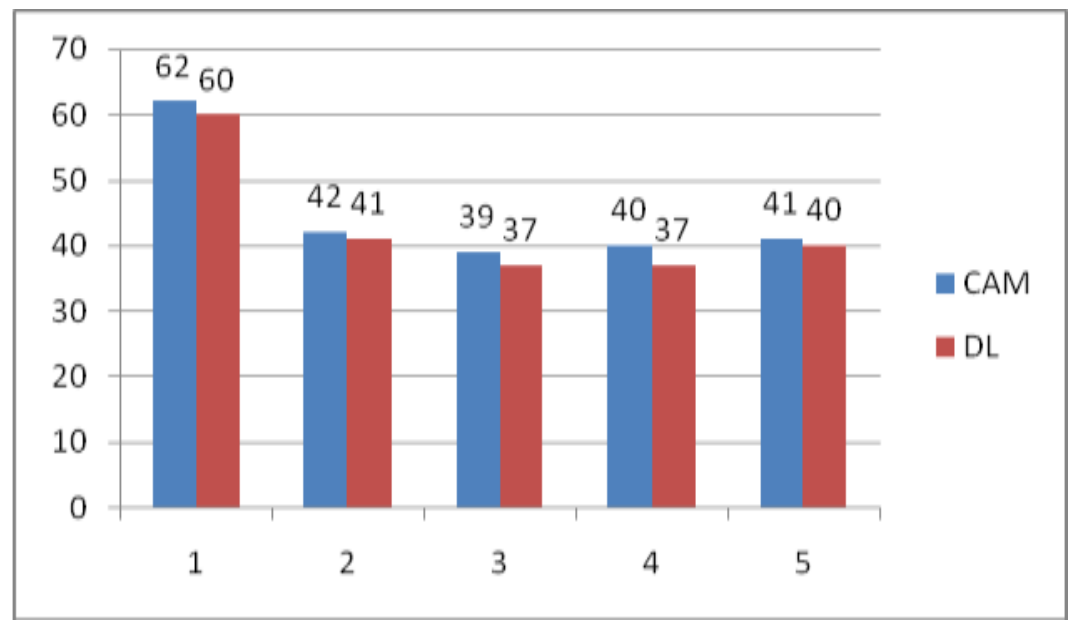

Fig. 1. Scores of each indicator between the first experiment and the second experiment classes

From table 1 and figure 1 , it can be seen that there is a difference of problem-solving abilities in each of indicators between the first experimental and the second experimental classes, but the difference is not significant. It means that viewed from each of indicators, the problem-solving ability of the two experimental classes tends to be the same, but regardless each of indicators, the artistic problem-solving ability shows a difference between the first experimental class taught using the concept attainment model and the second experimental class using discovery learning model. The posttest result of problem-solving ability can be seen in table 2 .

TABLE II. SCORES OF EACH INDICATOR BETWEEN THE FIRST EXPERIMENT AND THE SECOND EXPERIMENT CLASSES

\begin{tabular}{cllll}
\hline Learning Model & Lowest & Highest & Total & Average \\
\hline DL & 35 & 80 & 1085 & 54.25 \\
\hline CAM & 30 & 80 & 1120 & 56 \\
\hline
\end{tabular}




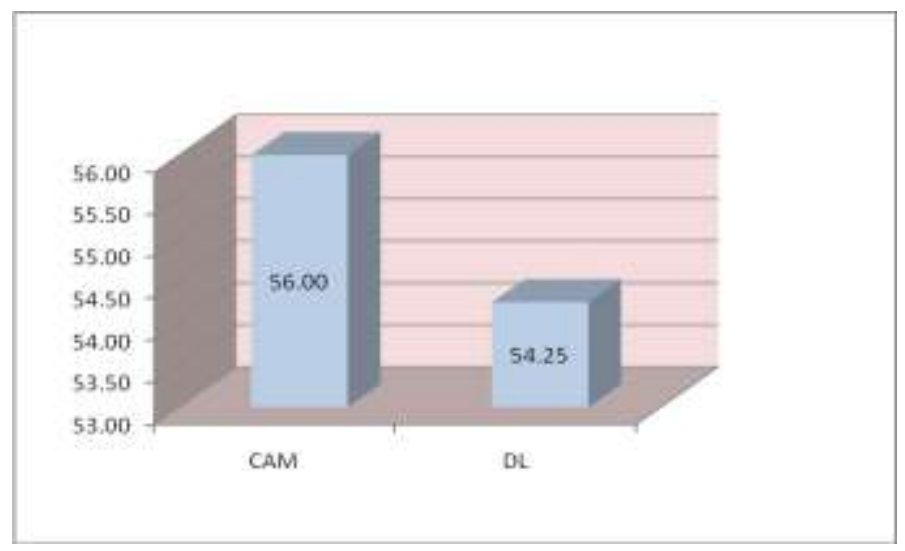

Fig. 2. The difference in average problem-solving abilities between the first experimental and the second experiment classes

Table 2 and figure 2 explain that there is a difference in problem-solving ability between the first experimental and the second experimental classes. The mean score of problemsolving ability for the class taught with concept attainment model is 56, while that for the class taught with discovery learning is 54.25 .

Next, the t-test is conducted. Before the t-test phase, the data was tested first to find its normality and homogeneity. The result of the normality test can be seen in table 1 .

\section{TABLE III. RESULT OF NORMALITY TEST ON POSTTEST SCORE OF THE FIRST (12TH SCIENCE 4) AND THE SECOND (12TH SCIENCE 3) EXPERIMENTAL CLASSES}

\begin{tabular}{llll}
\hline & Statistic & Df & sig \\
\hline CAM & 0.132 & 20 & 0.200 \\
\hline DL & 0.159 & 20 & 0.200 \\
\hline
\end{tabular}

From the normality test on the problem-solving ability's post-test score for the first and the second experimental classes, it can be seen that the samples were normally distributed normally. The rationale of decision making is that when significance or probability value $<0.05$, the data is not distributed normally. If the value of significance or probability value $>0.05$, the data is normally distributed normally. From the normality test table with KolmogorovSmirnov, it can be found that for the problem-solving ability of the first and second experimental classes is higher than 0.05 (0.200 and 0.200), it can be said that data problemsolving abilities are generally distributed at confidence interval of $95 \%$.

TABLE IV. RESULT OF HOMOGENEITY TEST ON POSTTEST SCORE OF THE FIRST ( $12^{\mathrm{TH}}$ SCIENCE 4$)$ AND THE SECOND (12 ${ }^{\mathrm{TH}}$ SCIENCE 3$)$ EXPERIMENTAL CLASSES

\begin{tabular}{lllll}
\hline \multicolumn{5}{c}{ Levene test } \\
& $\mathrm{F}$ & $\mathrm{df} 1$ & $\mathrm{df} 2$ & $\mathrm{Sig}$ \\
\hline CAM & 3.006 & 5 & 10 & 0.065 \\
\hline DL & 0.431 & 6 & 11 & 0.843 \\
\hline
\end{tabular}

From the homogeneity test results, it can be found that probability value of problem-solving ability is homogeneous. This rationale of decision is that if the value of significance or probability value $<0.05$, it can be said that the variant of two or more population data groups is not the same. If the significance or probability value $>0.05$, it can be said that the variant of two or more data groups of data population is the same. Data on the homogeneity test shows that problemsolving ability is 0.843 for the first and 0.065 for the second experiment classes, so it can be said that data problemsolving ability has the same variant or is homogenous.

After the data has been normal and homogeneous, independent sample t-test is conducted to find out whether there is a difference of problem-solving ability or not between students taught with concept attainment model and those taught with discovery learning model.

TABLE V. RESULTS OF DIFFERENCE TEST ON POSTTEST SCORE OF THE FIRST $\left(12^{\text {TH }}\right.$ SCIENCE 4) AND THE SECOND $\left(12^{\text {TH }}\right.$ SCIENCE 3$)$ EXPERIMENTAL CLASSES

\begin{tabular}{clll}
\hline Group & $\mathrm{N}$ & Mean & Sd \\
\hline CAM & 20 & 57.95 & 12.551 \\
\hline DL & 20 & 50.85 & 12.995 \\
\hline
\end{tabular}

The data shows the description of variables analyzed including the mean score of the problem-solving ability of 57.95 for the first experimental class with the standard deviation of 12.551 and 50.85 for the second experimental class with the standard deviation of 12.995 . Furthermore, FTest analysis of Ho hypothesis suggests that there is no difference of posttest value between the first and the second experiment classes. Ha states that there is a difference of posttest between experimental and control classes. If probability (significance) $>0.05$, Ho is supported. If probability (significance) $<0.05, \mathrm{Ha}$ is supported. From the result of the t-test, it can be found that the F statistic value of problem-solving ability is 0.015 with the probability value of 0.905 . Because of probability $>0.05$, Ho is not supported. It means that there is the difference between problem-solving ability between the first and the second experiment classes.

\section{B. Discussion}

The result of data analysis on problem-solving ability of the $12^{\text {th }}$ graders of SMAN 1 Karas academic year 2016/2017 on Evolution material using statistics analysis shows that there is the difference between the class taught with concept attainment model and the one class taught with discovery learning model. Problem-solving ability is considered as necessary to students, 
unusually high school students, as this ability can help students make informed, thorough, systematic, logical, and multifaceted decisions [13]. Paidi developed problemsolving indicators into five indicators: 1) defining problems; 2) Identifying the problem; 3) formulating alternative solutions; 4) determining the best solution; 5) problemsolving ability [14].

A study conducted by Kalani [8] found that 1) the achievement of students using concept attainment model is better than that using conventional method, 2) concept attainment model is more effective in achieving the concept of science, and 3) concept attainment model is more effective than conventional method in the term of concept retention. Ostad \& Soleymanpour [9] explain that the concept attainment model is essential to learn how to classify, how to think and how the students accept the concept. This model enables the students to be more sophisticated in conceptualization, inductive reasoning, dominance and knowledge of vision, perspective, tolerance to ambiguity and sensitivity to logical reasoning in communication. Learning with concept attainment model is conducted in some phases packaged in syntax form. This syntax, according to Joyz \& Weil [5], is divided into three phases: 1) data presentation and object identification; 2) concept achievement testing; and 3) strategic thinking analysis.

Joysz \& Weil further explain that in the $1^{\text {st }}$ phase of the model, the students' task is to develop a hypothesis about the nature of concepts based on examples and non-examples presented. In the $2^{\text {nd }}$ phase, the students examine the achievement of concept firstly by actual identifying additional examples, and secondly by making their examples. In the $3^{\text {rd }}$ phase, the students begin to analyze the concept strategy achieved, and then construct the concept. The procedure of the learning process with the concept attainment model will train students to identify a problem, to formulate and to test the hypothesis so that students will be trained to solve the problem. The relationship between syntax concept attainment model and the indicator of problem-solving ability is presented in the following table.

TABLE VI. RESULTS OF DIFFERENCE TEST ON POSTTEST SCORE OF THE FIRST (12 ${ }^{\text {TH }}$ SCIENCE 4) AND THE SECOND (12 ${ }^{\text {TH }}$ SCIENCE 3$)$ EXPERIMENTAL CLASSES

\begin{tabular}{lll}
\hline No & $\begin{array}{l}\text { Syntax of concept attainment model } \\
\text { (CAM) }\end{array}$ & Indicators of problem-solving ability \\
\hline 1 & $\begin{array}{l}1^{\text {st }} \text { phase } \\
\text { Students develop a hypothesis about the nature of } \\
\text { concepts based on examples and } \\
\text { non-examples presented. }\end{array}$ & 1. define the problem \\
\hline 2 & $\begin{array}{l}2^{\text {nd }} \text { phase } \\
\text { Students test the achievement of the concept, first } \\
\text { by actually identifying additional examples, and } \\
\text { secondly by making their examples. }\end{array}$ & 3. Formulate alternative solutions \\
\hline 3 & $\begin{array}{l}3^{\text {rd }} \text { phase } \\
\text { Students begin to analyze the strategy of } \\
\text { concepts that have been achieved, and students } \\
\text { will construct the concept. }\end{array}$ & 5. problem-solving skills. \\
\hline
\end{tabular}

From the table above, it can be explained that in the $1^{\text {st }}$ phase of CAM syntax, students develop a hypothesis about the essence of concept based on the example and nonexamples presented. In this phase, students will be trained to define the problem (the $1^{\text {st }}$ indicator of problem-solving ability). The $2^{\text {nd }}$ phase of the CAM syntax, students test the achievement of concept, firstly by actual identifying additional examples, and secondly by making their examples. In this phase, students will be trained to identify problems (the $2^{\text {nd }}$ indicators of problem-solving ability) and to formulate alternative solutions (the $3^{\text {rd }}$ indicators of problemsolving ability). The $3^{\text {rd }}$ phase of CAM syntax, students begin to analyze the strategy concepts that have been achieved and construct the concept. In this phase, students will be trained to determine the best solution (the $4^{\text {th }}$ indicators of problemsolving ability) and to solve problem-solving (the $5^{\text {th }}$ indicators of problem-solving ability).
Thus, learning by using the concept attainment model, students will be trained to solve problems, so that students will have a high problem-solving ability.

\section{CONCLUSION}

The result of the research shows that there is a significant difference in problem-solving ability between the class taught by using the concept attainment model and the one taught using discovery learning model. The problem-solving ability of students taught using the concept attainment model is higher than that using discovery learning model.

\section{ACKNOWLEDGMENT}

The authors would like to thank all of those who have helped this research, especially the students and the teachers of SMAN 1 Karas Magetan. 


\section{REFERENCES}

[1] Kemendiknas, Salinan Peraturan Menteri Pendidikan Nasional Republik Indonesia No. 41 Tahun 2007 Tentang Standar Proses untuk Satuan Pendidikan Dasar dan Menengah, Jakarta: Kemendiknas, 2007

[2] S.S. Handayani, \& B.A. Prayitno, "Pembelajaran Biologi dengan Concept Attainment Model menggunakan teknik Vee Diagram dan Concept Map Ditinjau dari Kemampuan Berpikir Kritis dan Penalaran Ilmiah," Jurnal Inkuiri Vol. 3, No II, pp 16-27, 2014

[3] A. Kumar, \& M. Mathur, "Effect of Concept Attainment Model on Acquisition of Physics Concept," Universal Journal of Educational research vol.1(3), pp 165-169. http://www.hrpup.orgDOI:10.13189/ujer.2013.010304

[4] R. Martomidjoyo \& Y. Nuryani, "Pembelajaran Biologi Sel Berbasis Ketrampilan Berpikir Kritis Menggunakan Concept Attainment Model,"

[5] Surakarta: Makalah Seminar Nasional VIII Pendidikan Biologi UNS, 2009

[6] B. Joyce, M. Weil, E. Calhoun, Model of Teaching. Yogyakarta: Pustaka Pelajar, 2016

[7] J.R. Mayer, Effect of Using The Concept attainment Model with Inductive Reasoning with High School Biology Students," Bozeman, Montana: Montana State University, 2012

[8] R. Bhargava, "Effect of Concept Attainment Model on Achievement in Social Sciences," International Journal of Science and Research (IJSR) ISSN (Online), pp 2319-7064, 2016

[9] J. Fraizer. Concept Attainment Model, Boulangerie (Bakery). An Educator's Reference Desk Lesson Plan. Randolph Macon Women's Collage, 1999.

[10] Shreelekha \& Nayar, The Effectiveness of Concept Attainment Model in Learning Chemistry at Secondary Level. NCERT publication New Delhi, 2004.

[11] N. Shamnad, Effectiveness of Concept Attainment Model on Achievement in Arabic Grammar of Standard IX Students. M.Ed. Thesis, Mahatma Gandhi University, 2005.

[12] A. Kalani, A Study of The Effectiveness of Concept Attainment Model over Conventional Teaching Method for Teaching Science in Relation to Achievement and Retention, Jaipur: S.S.G. Pareek P.G. College of Education, 2009

[13] G. Ostad \& J. Soleymanpour, The Impact of Concept Attainment Teaching Model and Mastery Teaching Method on Female High School Students' Academic Achievement and Metacognitive Skills. International Journal of Innovative Research in Science, Engineering, and Technology, 2014

[14] O.E. Oghenevwede, "Effects of Discovery and Inquiry Approaches in Teaching and Learning of Biology on Secondary Schools Students Performance in Delta State, Nigeria," Jornal of Research in Education and Society Vol. 1(1), April 2010.

[15] J.A. Troyer, J.R. Tost, M. Yoshimura, S.D. LaFontaine, A.R. Mabie, "Teaching Students How to Meditate Can Improve Level of Consciousness and Problem Solving Ability," International Conference on Education and Educational Psychology (ICEEPSY 2012) pp 153-161, 2012

[16] R. Sternberg, Cognitive Psychology. Yogyakarta: Pustaka Pelajar, 2008

[17] Paidi, Kemampuan Memecahkan Masalah. [Online]. Accessed from HTTP:staff.uny.ac.id/sites/default/files/132048519/ArtikelSemnas FMIPA2010 UNY.pdf, 2010. 